\title{
SPINEL - AS INDICATOR FOR DIAMOND.
}

Zhou Jianxiong; Zhang Andi; Wang Wuyi; Xie Xilin; Guo Lihe. Institute of Mineral Deposits, CAGS, 26 Baiwanzhuang Roa'd, Beijing 100037, China

This extendcd abstruct will concern primarily with macrocryst spinel classification.It is proposed first to discuss the spinel guoup populations of typical kimberlite and lamproite bodies, to discuss their significance for diamond exploration, and then to discuss thcir origin. Only the principal points summariged below. Detailed description of the each spincl group and discussion can be found in other papers (Zhang Andi, 1991; Zhou Jianxiong, 1991).

Spinel is one of the most characteristic minerals of kimberlite and lamproite. Although its amount in kimberlite and lamproite varies widely from trace quantities up to about $0.3-0.5 \%$ (Sobolev, 1975), it is very resistent to physical and chemical weathering, and it is easily found in the concentration. They are abundant enough to act as indicator for primary sourcc rock. There have been some successful examples in China. Onc of diamond bearing kimberliee pipe and one of diamond bering lamproite field wcre found by tracing spinels.

Howerer, for a long time, as Mitchell said (1987), determining provenace of spincl is still very difficult.It is analogous to the olivine macrocryst problem. And the composition of spincls from kimberlite and lamproite are similar to that of spincls from a wide varicty of basic and ultrabasic rocks. Recently the people found the diamond bering rocks always contain spinels which show similar chemical features to the mineral inclusions in diamond (Gurney, 1989, Dong and Zhou 1980).

In this study the classification of spinel is made by $\mathrm{Q}$-cluster analysis, based upon the predominance of $\mathrm{Cr}_{2} \mathrm{O}_{3}, \quad \mathrm{Al}_{2} \mathrm{O}_{3}, \quad \mathrm{TiO}_{2}$ and $\mathrm{MgO}$. The nearly 5000 analyscs from above 68 rock bodies have been studed.Most of quantitative analyses wcre made by typical EPMA, that is wavelength dispersive spectrometry our lab. Very few came from the reference. The occurences of spinels include in diamondiferous or barren kimberlites and lamproitcs, and other reletive rocks, such as lamprophyres, basalts, alpine peridotities, layercd basic intrusions and meteorite and so on. which arc not only from 6 provinces in China, but also from South Africa, Australia, Amcrica and USSR.Fig.l and Table 1 summary the main results obtained by the cluster analysis. These all 12 groups involve almost the all spincls occured in above mentioned rocks. It is obvious that each group is characterized by differentc $\mathrm{TiO}_{2}, \mathrm{Al}_{2} \mathrm{O}_{3}, \mathrm{Cr}_{2} \mathrm{O}_{3}$ and $\mathrm{MgO}$ contents. And it is casily recognized by computer program based upon thd amount of compositions. S1, S2 and S3 groups with very high $\mathrm{Cr}_{2} \mathrm{O}_{3}$ and $\mathrm{MgO}$ are all direct indicators for diamond. They all contain very low $\mathrm{Al}_{2} \mathrm{O}_{3}$ and $\mathrm{TiO}_{2}$, although they have a little diffrent each other. $\mathrm{S} 1$ group almost does not contain $\mathrm{TiO}_{2}$. S2 group contains about $1 \% \mathrm{TiO}_{2} . \mathrm{S} 3$ group contains very high $\mathrm{Cr}_{2} \mathrm{O}_{3}$ and $\mathrm{MgO}$, mainly found in meteorite. $\$ 4$ guoup can be found in a variety of occurences, including kimberlite and lamproite. Usually this guoup were further subdivided according to the $\mathrm{TiO}_{2}$ content. S5 guoup with high $\mathrm{Al}_{2} \mathrm{O}_{3}$ is not typical to kimberlite and lamproite. $\mathrm{S} 6$ group with low $\mathrm{Al}_{2} \mathrm{O}_{3}$ and high $\mathrm{TiO}_{2}$ is typical for kimberlite, and sometimes found in lamproitc. 57 group with high $\mathrm{Al}_{2} \mathrm{O}_{3}$ and $\mathrm{TiO}_{2}$ is typical for lamproite, but also found in kimberlite, especially 
in mica kimberlite. Other groups are not very importent and very easy to discriminate. This classification has been proved very uscful for following three fields:

(1) Simplifing the quantitative description for spinel groups in kimberlite, lamproite and other rocks. Fig2 shows the spinel group populations in a few typical kimberlites and lamproites which are characterized for each rock.

(2) Simplifing the description for spinels from nature concerntrates.It is very useful to exploration of diamond.

(3) Studing spincl origin.
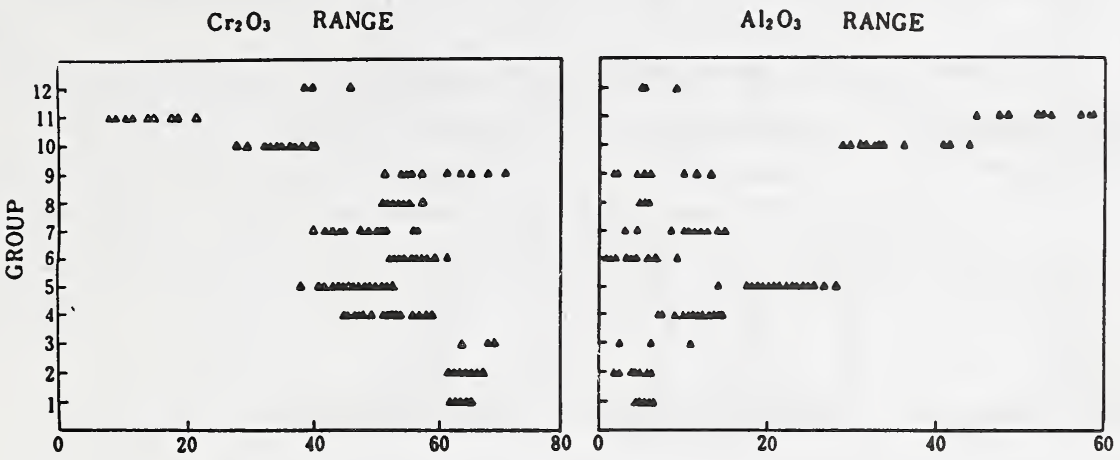

$\mathrm{TiO}_{2}$ RANGE

MgO RANGE
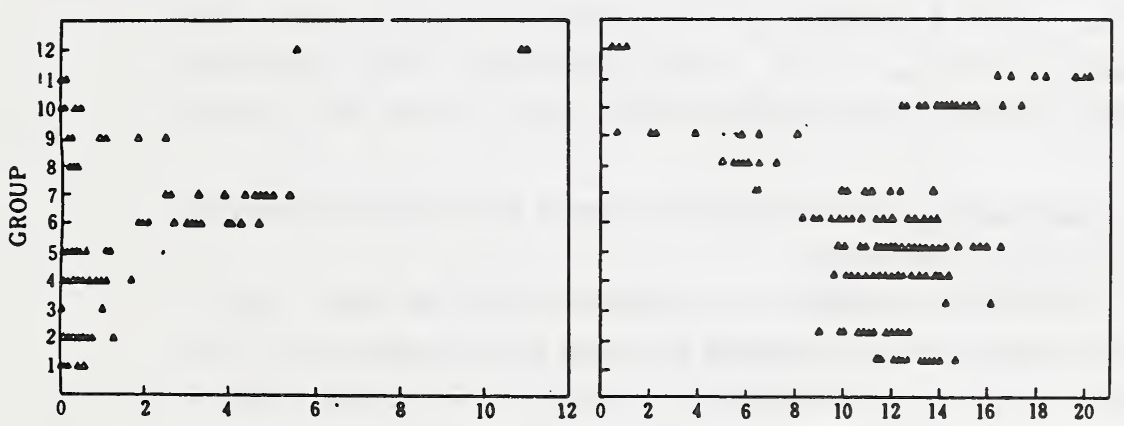

Fig.1. Compositional ranges for 12 group spincls. Obtained by cluster analysis. It shows the different among 12 group spincls.

Table 1. Averaged compositions each group

\begin{tabular}{|c|c|c|c|c|c|c|}
\hline Group & Name & $\mathrm{TiO}_{2}$ & $\mathrm{Al}_{2} \mathrm{O}_{3}$ & $\mathrm{Cr}_{2} \mathrm{O}_{3}$ & $\mathrm{MgO}$ & Occurences \\
\hline S1 & poor Ti, Al rich Mg chromite & 0.12 & 5.29 & .64 .00 & 12.72 & Inc KimD LamD \\
\hline S2 & titanian poor Al rich M g chromite & 0.42 & 4.29 & 64.63 & 11.07 & Inc KimD LamD \\
\hline S3 & High M g. Cr chromite & 0.36 & 6.54 & 67.37 & 15.43 & Met Inc KimD \\
\hline S4 & poor Ti rich Al. Mg chromite & 0.48 & 12.17 & 52.81 & 11.69 & Lay Chr Lam Kim \\
\hline S5 & poor Ti high Al chromite & 0.43 & 21.67 & 47.21 & 13.04 & Lap Kim Chr \\
\hline S6 & rich Ti poor Al chromite & 3.14 & 3.87 & 57.52 & 10.89 & Kim Lam \\
\hline S7 & hith Ti rich Al chromite & 4.08 & 10.25 & 48.43 & 10.32 & Lam Kim2 \\
\hline S8 & poor Al low M chromite & 0.28 & 3.35 & 54.51 & 5.91 & Ler \\
\hline S9 & low Ti rich Fe chromite & 0.68 & 6.17 & 60.71 & 3.56 & Met Chr \\
\hline S10 & poor Ti rich Cr Mg-Al spinel & 0.13 & 34.14 & 35.38 & 14.40 & Lap Kim \\
\hline S11 & chrome Mg-Al spinel & 0.06 & 52.50 & 14.35 & 18.56 & Bas \\
\hline S12 & high Ti rich Fe chromite & 9.15 & 6.49 & 41.77 & 0.72 & Met \\
\hline
\end{tabular}

Notes: Inc. inclusion in diamond; KimD, diamondiferous kimberlite; LamD, diamonodiferous lamproitc: Kim, Kimberlite; Kim2, mica kimberlite; Lam, lamproite; Lay, layered basic intrusion; Chr, alpinc chromite deposits; Lap, lamprophyre; Ler, Iherzolite; Met, metcorite; Bas, basalt. 

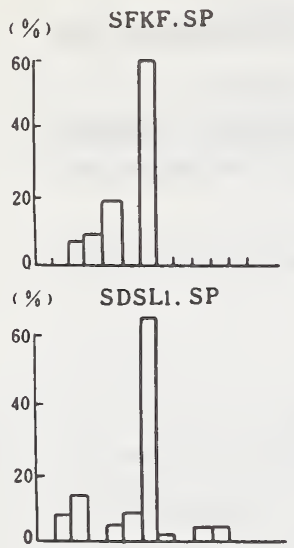

(\%) SDHQ6.SP

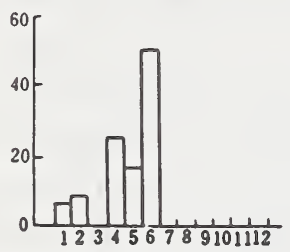

LN50.SP

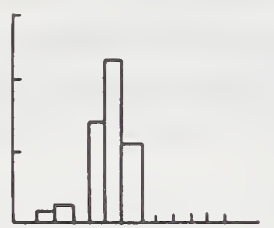

HNTM.SP

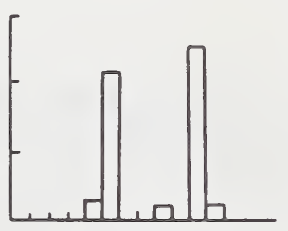

SXLL.SP

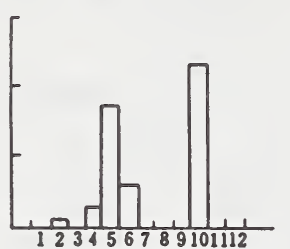

ED4. SP

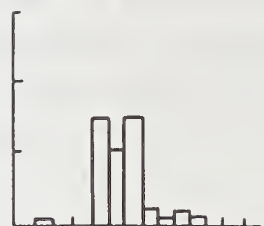

MP1.SP

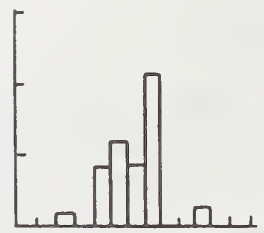

JS7.SP

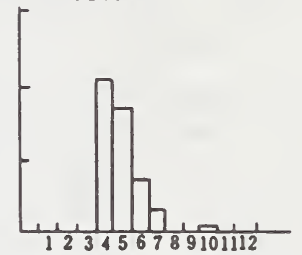

Fig. 2 Histograms of spinel group population from some typical kimberlites and lamproites.Diamondferous: SFKF, Koffiefontein SA; ED4, Ellendal,WA; SDSL1, Shandong SL1 China; SDHQ6, Shandong HQ6 China: LN50, Liaoning LN50 China; MP1, Guizhou MP1 China, lamproite; Barren: HNTM, Hunan TM China; SXLL, Shanxi LL China; JS7, Hubei JS7 China, lamproite.

The results of present studing show the following criterias which the geologists must consider during the exploration of diamond:

(1) Chemically spinels from kimberlites and lamproites exhibit the widest ranges in $\mathrm{TiO}_{2}, \mathrm{Al}_{2} \mathrm{O}_{3}, \mathrm{Cr}_{2} \mathrm{O}_{3}$ and $\mathrm{MgO}$ contents comparing with those of non-kimberlites. This is a very importent criteria which we must consider any time. The distrbution figers of $\mathrm{Cr}_{2} \mathrm{O}_{3}-\mathrm{Al}_{2} \mathrm{O}_{3}, \quad \mathrm{Cr}_{2} \mathrm{O}_{3}-\mathrm{TiO}_{2}$ and $\mathrm{Cr}_{2} \mathrm{O}_{3}$ and $\mathrm{Cr}_{2} \mathrm{O}_{3}-\mathrm{MgO}$ are very importent for estimating of source rocks.

(2) Macrocryst spinels can be considered to be xenocrysts derived from dunites, harzburgites, lherzolites and pyroxenite which have different $\mathbf{P}$ and $T$ physical conditions.In other words, as the paragenesis from dunite to pyroxenite the $\mathrm{Cr}_{2} \mathrm{O}_{3}$ in spincl decreases with similtaneous increase in amount of $\mathrm{Al}_{2} \mathrm{O}_{3}$. That is why that diamondiferouse rocks usually contain more groups than barren rocks.

(3) S1 and S2 group spincls directly indicate if the diamond present or not.Diamond bearing kinberlites or lamproites always contain these spinels (sce Fig.2). It is possible to use these spinels as semiquantitative criteria. These spinels can be called syngenetic chromite with diamond or diamond phase chromite, and may be used as indicator for finding of new source rocks.

(4) S6 group spinel is very special indicator for kimberlite, S7 group spinel is very special indicator for lamproite. It is very clear to see in the Fig. 2. Only in barren rocks S6 and S7 groups were replaced by S5 and S10 groups, for example, the spinels in Hunan and Shanxi kimberlite fidles, China (Fig.2) .

(5) According to above mentioned criteria, a comprehensive understand about spinel in a kimberlite or lamproite body can be made based upon at least 50 grain spinel 
analses.It means that more analyses of spinel must be done during the cxploration, otherwise it is possible to lose useful information.

(6) Spincls from reletive rocks are different from spinels in kimbcrlices and lamproitcs in spinel group population.It is easy to discriminatc each other.

\section{Reference}

1. Zhang Andi et al., 1991, Database of Indicatar Minerals for Diamond (in Chinese with English abstruct) .

2. Zhou Jianxiong et al., 1991, Classification of spinel and its significancc (in press).

3.Sobolev N.V. et al., 1975 Geology and Geophys cs V.16, No.11, P.7-24.

4. Mitchell R. H.,1986, Kimberlites: Mineralogy, Geochcmistry and Petrology.Plenum Publ. Corp., New York.

5.Gurncy J.J., 1989, Kimberlites and Releted Rocks V.2, P.935-965.

6. Dong Zhenxin. and Zhou Jianxiong, 1980, Acta Geobgica Sinica, No. 4, P.284-299. 